\title{
XIIth INTERNATIONAL CONFERENCE OF SOCIAL WORK
}

Meeting for the twelfth time since its foundation in 1928, the International Conference of Social Work pursued its mission of information exchange and research. Unceasingly widening the horizons of all who are concerned with social problems, it suggested as the theme for its Athens Meeting in September 1964 the topic Social Planning and it analysed the rôle of Social Service as well as assistance in social development plans.

Now that it is more than ever necessary to plan ahead, in order to avoid those pitfalls of our civilization's rapid evolution which jeopardize the general welfare and the interests of the individual, the time is ripe for all of us to think about this problem.

The International Conference, which aims at constituting a world-wide forum, always comes nearer to achieving this objective. Not only the participants in the Conference, but the speakers too, came from every continent to relate their experiences and exchange ideas. Side by side, under the chairmanship of a representative of India, sat delegates from Poland, Uganda, and Greece to explain the planning problems arising in their countries. Another particularly interesting session was that in which France, Australia and Ethiopia in turn described the rôle of social service planning in the "mushroom towns" in their countries. Due to industrialization, emigration and the exodus of rural populations, the growth of towns opens up a wide field of activities for social services. Many other examples could be cited.

Commissions and study groups reviewed many present-day Social Service problems, examining the importance of Social Service in planning and the rôle it plays today, albeit often unobtrusively and even timorously. Nevertheless, there does appear to be emerging a new generation of social workers whose training is focused less on the individual than on society. In order that planning should not be restricted to economic aspects, as has been the case so far, the social workers' contribution is essential. 


\section{Miscellaneous}

The report of the preliminary meeting, which took place at Chalcis on Euboea Island, a few days before the Conference, provided a useful guide. It summarized as follows the contribution. which Social Service can make to social planning :

- knowledge and understanding of people's needs, acquired through social work experience and the close personal contacts involved ;

- information about the effects of social changes and how people adjust to them, arising from an understanding of human behaviour and the influence of environmental factors ;

- professional judgment based on an understanding of human motivation in relation to needs and environment and on a "total " view of the effects of apparently separate parts of a plan ;

- a knowledge of how to induce people to participate in cooperative action and undertakings, which will enable them to achieve personal satisfaction, assume leadership, and accept responsibility ;

- relevant proposals for the best solutions to social problems which frequently arise out of the whole range of economic and social changes (for example, the breakdown of family structures and social controls).

How could social work make its contribution?

- by active participation at all stages of social planning ;

- by provision of qualitative information based on practical experience in dealing with people ;

- by provision of relevant satistical data;

- by helping to formulate objectives;

- by social surveys ;

- by advising on the means for effective citizen participation.

By encouraging and facilitating active citizen participation the Social Service will set its stamp on any socio-economic planning and its work will be constructive and lasting. 
Social services, by participating in general planning, acquire a better understanding of their relations with other institutions and of their places in the various social welfare programmes. As a consequence, stimulated to examine the genuine needs of those in their care and having at the same time to judge whether the very framework of assistance is in keeping with the requirements of a changing society, they will come to a closer agreement among themselves. Many social workers will gain a new perspective of society's profound stirrings when they grapple with the responsibility of drawing up and carrying through plans that will transform the lives of the people for whom they are concerned.

Their own experience will be useful to others. For instance, during one of the plenary sessions of the Conference, Mr. C. A. Doxiadis recalled that, in the first place, the architect commissioned to construct large community settlements should be given guidance. He went on to say:

We cannot effect changes overnight, because we are working with human beings. We can experiment up to a certain degree; but we cannot say that we are going to force a group of people to live in a community which $I$ as an architect have conceived, for if we decide to select people as guinea-pigs and tell them that we are placing them in this completely new type of community just to test how successful it is, we can rest assured that their reaction will no longer be a natural one. Once they know that they are guineapigs they will react in a different way, and we cannot be sure of our findings. We must therefore say: we must build this whole system of interconnections into a science, we must learn empirically from what we have, we must experiment, develop a theory, test the theory, feedback, ameliorate the theory, experiment again, and so on-which means turning every one of us dealing with man, society, or bricks and mortar, into more and more scientificminded people. To be scientific-minded, we should be progressive in desire : conservative when offering solutions to those matters in which we have a vast experience, while expressing ourselves very progressively when dealing with forces with which man has not dealt before...

. . . Sometimes I have to turn to a social scientist and ask him how he could help me face a certain problem, but his recommend- 


\section{Miscellaneous}

ation frightens me. For he recommends that we invite so many people to consult that we finally need a new settlement merely to house the consultants who are going to take care of the settlements to be built. My need, I admit, is not only to develop a science, but to build something which will be a little better, if possible, than what we have. In order to do that, we need from you-the social scientists, the social workers-a very coherent image of what we should do. If we get it from you we can make the effort to build the shell and therefore help man himself.

A new chairman was chosen, in the person of Professor Eugene Pusic (Yugoslavia). The next Conference will be held in Washington, in July 1966 ; it will be preceded by a discussion in Amsterdam from July 19-24, 1965, and the theme will be "Urban Development and its Relation to Social Service".

M.-L. CORNAZ

Director, School for Social Studies, Geneva

\section{WORKING FOR A WORLD AT PEACE}

In the February issue of the Deutsches Rotes Kreuz (No. 2; Bonn) an article by Mr. Willy Heudtlass, Head of the Press and Radio Service of the German Red Cross in the Federal Republic, deals with the problem of assistance to developing countries. The author stresses that, in gratitude for the high living standard they enjoy, some nations should develop assistance programmes for those who need help, including help in the humanitarian field. Whoever dowbts the effectiveness of such aid cannot but admit that, under the banner of the Red Cross, men are dedicating their lives with courage to the building of a better world.

The author's concluding paragraphs are as follows :

Assistance to developing countries, it may be said, is also carried out by the Red Cross, not in the sense usually attributed to the term, that is assistance primarily to enable those countries to 